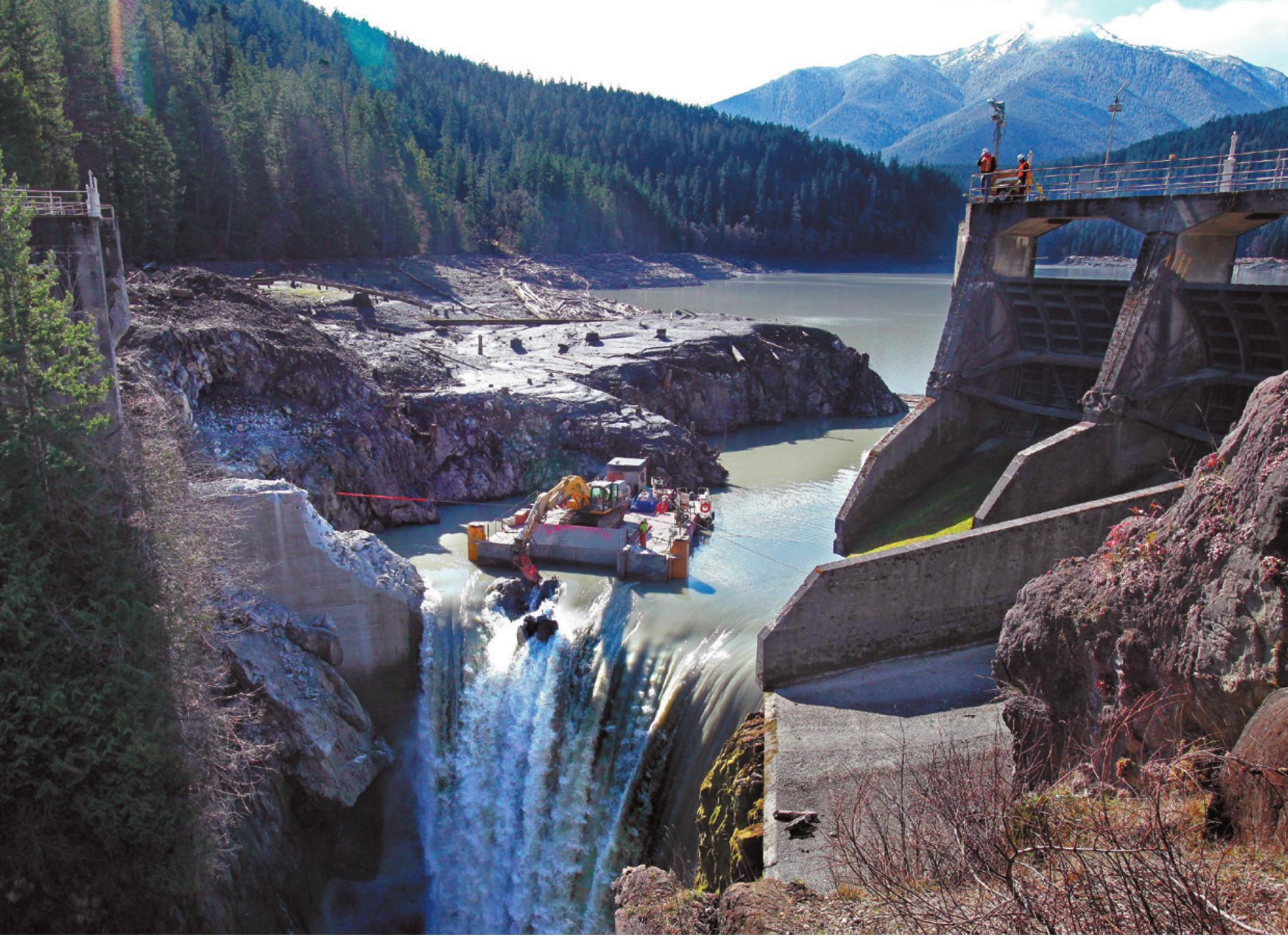

\title{
Rivers on the run
}

\section{As the United States destroys its old dams, species are streaming back into the unfettered rivers.}

\author{
BY RICHARD A. LOVETT
}

$\mathrm{J}$

ust outside the small town of Stabler in Washington, hydrologist Bengt Coffin surveys a mountain river that he helped to revive from a decades-long coma.

Today, the clear waters of Trout Creek run fast and cool between banks covered in young alder trees. But just five years ago, an 8-metre-high concrete wall blocked the river at this site. The dam and the reservoir behind it had tamed the river and made it difficult for endangered steelhead trout (Oncorhynchus mykiss) to reach their spawning grounds upstream.

In 2009, Coffin led the US Forest Service effort to remove the dam, and Trout Creek has since regained the look of a young river. Vegetation has covered the scars left by the dam and reservoir, and steelhead and other s species have started to rebound.

The revival of Trout Creek is part of a growing trend in the United States. About half of the nation's roughly 85,000 known dams no longer serve their intended purposes, and an increasing number are being

removed. Around 1,150 have gone so far, mostly in the past 20 years, according to a tabulation by the watchdog group American Rivers in Washington DC. In an era when many countries are still building dams, the United States is taking them out. "It used to be a crazy idea. Now it's accepted," says Amy Kober, director of communications for American Rivers.

Most of the demolished structures were lower than 5 metres, but in the past few years, projects in the Pacific Northwest have removed much

\section{$\rightarrow$ NATURE.COM}

For a video and

slideshow of dam

removals, see:

go.nature.com/m11diz taller ones. At the top end of the spectrum, the US National Park Service is dismantling the 64-metrehigh Glines Canyon Dam, the largest of a pair of big dams on Washington's Elwha River. Many of the larger dams were removed because their operators decided that it was too costly to bring the old 
structures in line with modern safety and environmental requirements.

The power companies' actions are boons for fish advocates who seek to restore populations of endangered species in the rivers. The damelimination trend has also provided an unanticipated research opportunity, because the projects have used diverse approaches to minimize the damage caused by unleashing huge floods of water and decades of accumulated sediment. Some efforts take a slow path, restoring river flow over months or years. Others use explosives and other engineering techniques to drain reservoirs within hours.

Data are still preliminary, but they suggest that both approaches can bring rapid benefits - not just to fish, but also to the habitat on which they depend. The rivers are rebounding at the sites studied so far, says Amy East, a geomorphologist with the US Geological Survey (USGS) in Santa Cruz, California. "We've seen a lot of resilience."

\section{OUT OF COMMISSION}

At Trout Creek, Coffin and his colleagues decided to take the cautious route when removing the ageing Hemlock Dam. Built in 1935, the structure provided power and irrigation for a nearby tree nursery that shut down in 1997. It had a fish ladder to allow animals to bypass the dam and swim upstream, but it was poorly built by modern standards and the number of fish using it had steadily declined.

A bigger concern was the reservoir, which had been steadily filling in with silt. By the time the dam was dismantled, the reservoir had become so shallow that it was possible to wade all the way across, says Coffin, waving a hand at mid-thigh level to show the depth of the water. In the midsummer sun, temperatures in the water could reach $26^{\circ} \mathrm{C}$ - too warm for steelhead, he says.

When the Forest Service decided to remove the dam, it was particularly concerned about the mud, sand and gravel that had built up in the reservoir. Coffin and others worried that flooding the river with all that sediment would harm the steelhead below the dam in Trout Creek. "All of our baby fish are down there," Coffin says. "We didn't want to decimate them."

The solution was to divert the river into a big pipe and then hire a fleet of dumper trucks to carry away the exposed sediment. In the process, the workers rediscovered the creek's original channel through the reservoir bottom and reinforced its banks with logs to stop them from eroding.

All those efforts seem to have worked. When water was first allowed to flow back through the old reservoir bottom, it initially ran muddy. But just seven hours later, Coffin's team documented the first steelhead venturing into the new channel above the old dam site. "It was that clear," he says.

Since then, the number of steelhead in the river and its tributaries has more than doubled, says fisheries biologist Patrick Connelly at the Columbia River Research Laboratory in Cook, Washington, although he notes that fish populations are variable enough that it will take several years to know whether the trend will continue.

Returning steelhead are not the only signs of success. Just above the old dam site, Coffin winds his way through patches of alder trees that were planted after the dam was removed, then crosses a rocky beach to the river. The rounded stones range from the size of potatoes to loaves of bread, and make for tricky footing. But Coffin is thrilled to see them because none of these ankle-breakers was here when the dam was first taken out. "All of this washed in," he says.

The cobbles provide nesting spots for the trout and a habitat for the insects that the fish eat. "People pay attention to the big animals," Coffin says, "but the bugs are an important part of the system." Reaching into the water, he plucks out a couple of rocks, turns them over and points out six types of insect clinging to the underside, including caddisfly larvae and a stonefly. "The year after the dam was removed, these wouldn't have been here," he says with satisfaction.

Elsewhere in the Pacific Northwest, teams opted for much more extreme measures to remove the 14-metre-tall Marmot Dam on Oregon's Sandy River in 2007 and the 38-metre-tall Condit Dam on Washington's White Salmon River in 2011.

The dams, both nearly a century old, were too big to take the same approach as at Trout Creek, where it had cost nearly US $\$ 1$ million to cart away 42,000 cubic metres of sediment. Marmot had nearly 20 times more sediment and Condit had double that of Marmot. Because it would be too expensive to dig out that material and carry it away, project managers opted for a more radical approach, colourfully described as "blow and go", in which the dams were removed quickly, says Gordon Grant, a research hydrologist at the Forest Service's Pacific Northwest Research Station in Corvallis, Oregon.

The results were impressive - but very different at the two sites. At Marmot, the sediment contained an equal mixture of sand and gravel. Once exposed to river action, it eroded out relatively quickly but sedately, with about half of it gone within 8 months. Researchers were surprised to find that the fish seemed little affected — the first curious salmon poked its nose back towards the former dam site within a day.

At Condit, the sediment contained a higher proportion of fine-grained material: $35 \%$ mud, $60 \%$ sand and just $5 \%$ gravel. The result was predictable in retrospect, but nobody anticipated it.

When engineers blew open a hole at the bottom of the dam, a jet of black liquid shot out as if from a giant fire hose. Instead of the expected flood of water, what came out was more like a mudflow, as waterlogged sediment from the reservoir slumped into the rapidly dropping water, then blasted downriver in a slurry that was as much as $28 \%$ sediment by volume. The reservoir lost its water and much of its sediment load in three hours. "It was almost like a volcanic event," says Jon Major, a geomorphologist at the USGS's Cascades Volcano Observatory in Vancouver, Washington. The 5-kilometre-long stretch of river between the dam and its confluence with the Columbia River temporarily became a muddy wasteland. With this kind of approach, says East, the slug of sediment wipes out everything, but the river can start recovering much sooner.

The National Park Service took a much more conservative approach to removing two large dams on the Elwha River, because the stakes were higher. The upstream portions of the Elwha drain more than 100 kilometres of pristine habitat on the north side of Washington's Olympic National Park. A river that large produces a lot of sediment: an estimated 18 million cubic metres was expected to escape from behind the dams, says Jason Dunham, an aquatic ecologist at the USGS office in Corvallis. That is the equivalent of filling eight typical American-football stadiums. And before the dams cut the number of salmon returning each year to around 10,000, the Elwha supported hundreds of thousands of fish.

Unwilling to risk the blow-and-go approach on both dams, engineers opted for a compromise. They quickly removed the lower, 32-metre-high Elwha Dam, which contained only about one-sixth of the total sediment. But the upstream Glines Canyon Dam, which is twice as big, is coming out in a series of steps that have so far lowered it to a 9-metre stub of its former self. East compares the method to deciding whether to uncover a wound quickly or gradually. The approach on the Elwha, she says, is like "pulling the Band-Aid off slowly, over the course of three years".

The good news in these giant projects is that scientists have not seen any serious harm from the feared releases of sediment. Instead, the rivers have proved unexpectedly efficient at flushing the worst of the mud downstream towards the sea, rather than letting it accumulate in river-choking mudflats. "It was not the big catastrophe people thought," East says.

Emily Stanley, a river ecologist at the University of Wisconsin-Madison who has studied dam removals for more than a decade, agrees that it is hard to think of one that had "catastrophically awful" results. (The one exception, she says, was an event in the 1970s, when the demolition of a dam on the Hudson River allowed sediment containing high levels of 


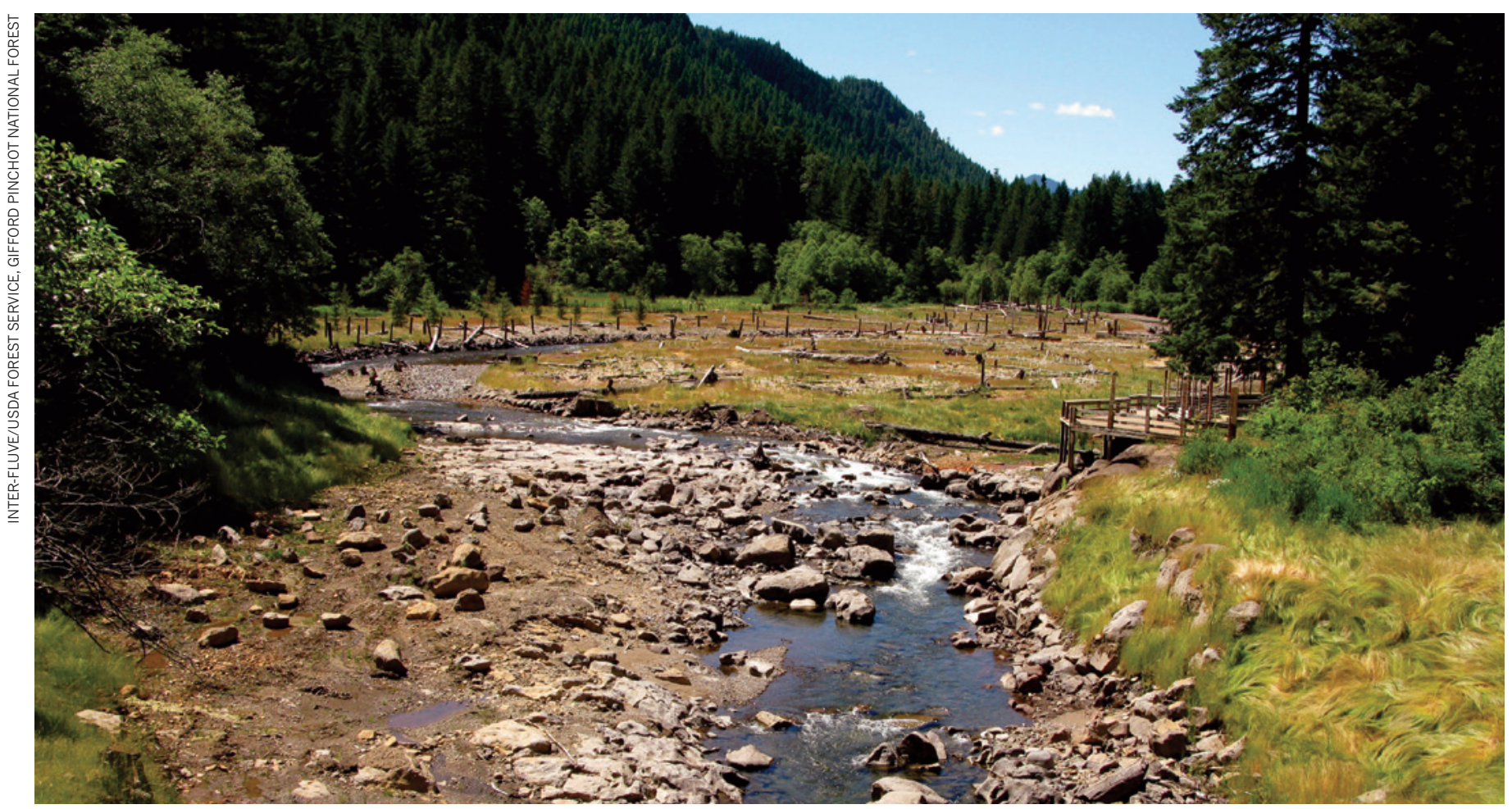

A reconstructed section of Trout Creek in Washington runs through the site of a former reservoir in 2010, a year after Hemlock Dam was removed.

toxic chemicals called polychlorinated biphenyls (PCBs) to escape from the reservoir and flow downstream.)

Data on the recent dam removals suggest that the fish are now coming back to the unfettered rivers. At Condit, fish were seen returning within weeks of the explosion. Two years later, the total exceeded 5,500, including steelhead and spring Chinook (Oncorhynchus tshawytscha), which had been effectively extirpated from the river, says Jody Lando, a quantitative ecologist with Stillwater Sciences in Portland, Oregon, who reported her results in May at an aquatic-sciences meeting in Portland.

Even on the Elwha, where the Glines Canyon Dam still impedes the river, East says that hundreds of salmon have been seen spawning in the lower dam's former lake bed. "That hasn't happened in over a hundred years," she says.

In part, these successes may reflect the fact that the Pacific Northwest is a landscape built by geological disturbances - volcanic outbursts, landslides and floods. Local wildlife has had to adapt to such upheavals, and salmon do that by not always returning to the precise stream of their birth. "There's a fair amount that stray," says East. It is those strays that repopulate any previously inaccessible habitat.

But other parts of the United States have also seen dramatic fish returns. On south-central Wisconsin's Baraboo River, the removal of a string of dams has allowed sturgeon to reach their former spawning grounds. And in New England, the destruction of two dams 7-9 metres high on Maine's Kennebec River and one of its tributaries has allowed Atlantic alewives (Alosa pseudoharengus) to repopulate 100 kilometres of previously blocked-off river. In 1999, before the first dam was taken out, no alewives were recorded in the upper part of the watershed, says Serena McClain, head of river restoration for American Rivers. By 2013, the annual run had rebounded to around 3 million.

\section{QUAKE CONCERNS}

The next big structure destined for retirement is the 32-metre-tall San Clemente Dam on California's Carmel River. The 93-year-old dam, which was originally built to provide drinking water, is coming out because of concerns over its safety during an earthquake. And there are expensive homes that could be flooded if even modest amounts of sediment were to escape and raise the stream bed, so the dam-removal plan seeks to avoid that, says East. Instead, the $\$ 84$-million project will cut a notch in a ridge near the upstream end of the reservoir, then divert the water into a nearby drainage that rejoins the original river downstream of the dam. "It's a major engineering feat," she says.

Researchers say that the surge in large dam removals in the past ten years has offered valuable insight into how rivers and their ecosystems respond to letting the water flow freely. But because every river and dam is different, it is hard to draw simple lessons that will apply in all situations, says Jim Pizzuto, a fluvial geomorphologist at the University of Delaware in Newark.

Still, the projects have shown that fish are remarkably adept at finding their way back. "If you un-build it, it seems like they will come back," says Grant.

At least, that is the sense emerging from the limited data so far. Researchers are struggling to get detailed statistics on fish recovery partly because removal projects tend to be planned according to engineering standards, not ones focused on fish and other river residents. And when fish assessments are done, they tend to be carried out by various state and federal agencies that share data only to a limited degree. "A lot of studies wind up on someone's computer, somewhere," says McClain.

But that may be changing because ecological considerations are increasingly part of dam-removal projects. A case in point is Maine's Penobscot River, where a \$62-million public-private partnership is buying dams and removing them to provide better access for fish to more than 1,600 kilometres of the river and its tributaries.

For a country once so bent on taming rivers, attitudes are quickly evolving. At the site of the former Condit Dam, a couple pulls into the car park and walks to a spot overlooking the water. "I come from a dambuilding family," says the man. "My father used to build things like this down in California - the Feather River, the Rubicon, the Yuba. I helped."

He pauses.

"A hundred years is a great thing, isn't it? Now we're busily employing people to undo what our ancestors screwed up." He stares silently for a moment at the ribbon of river, flecked with foam, 40 metres below. "It's a great thing." -

Richard A. Lovett is a freelance writer in Portland, Oregon. 